\title{
EVALUATING FORM AND FUNCTIONALITY OF PAY-FOR-PERFORMANCE \\ PLANS: THE RELATIVE INCENTIVE AND SORTING EFFECTS OF MERIT PAY, BONUSES, AND LONG-TERM INCENTIVES
}

\author{
Sanghee Park (spark@smlr.rutgers.edu), Rutgers University \\ Michael C. Sturman (mcs5@ cornell.edu), Cornell University
}

\section{Citation:}

Park, S., \& Sturman, M. C. (2016). Evaluating form and functionality of pay-for-performance plans: The relative incentive and sorting effects of merit pay, bonuses, and long-term incentives. Human Resource Management, 55, 697-719. 


\title{
EVALUATING FORM AND FUNCTIONALITY OF PAY-FOR-PERFORMANCE PLANS: THE RELATIVE INCENTIVE AND SORTING EFFECTS OF MERIT PAY, BONUSES, AND LONG-TERM INCENTIVES
}

\begin{abstract}
Using two-year longitudinal data from a large sample of US employees from a service-related organization, the present study investigates the relative effects of three forms of pay-forperformance plans on employees' job performance (incentive effects) and voluntary turnover (sorting effects). The study differentiates between three forms of pay: merit pay, individualbased bonuses, and long-term incentives. By definition, these PFP plans have different structural elements that distinguish them from each other (i.e., pay plan form) and different characteristics (functionality), such as the degree to which pay and performance are linked and the size of the rewards, which can vary both within and across plan types. Our results provide evidence that merit raises have larger incentive and sorting effects than bonuses and long-term incentives in multi-PFP plan environments where the three PFP plans are operating simultaneously. Only merit pay has both incentive and sorting effects among the three PFP plans. The implications for the PFP-related theory, as well as for the design and implementation of PFP plans, are discussed.
\end{abstract}

Keywords: Pay-for-Performance plans, Incentive effect, Sorting effect, Compensation 
Theory and empirical evidence indicate that, in general, pay-for-performance (PFP) plans have positive effects on employee job performance (e.g., Gerhart \& Fang, 2014; Gerhart \& Rynes, 2003; Jenkins, Mitra, Gupta \& Shaw, 1998; Lawler, 1971; Zenger, 1992). A common component of compensation systems, PFP plans are referred to as "pay that varies with some measure of individual or organizational performance" (Milkovich, Newman, \& Gerhart, 2013, p.335). Theory attributes the influences of PFP plans to two broad sets of effects: incentive effects and sorting effects (Cadsby, Song, \& Tapon, 2007; Gerhart \& Fang, 2014; Gerhart \& Milkovich, 1992; Gerhart \& Rynes, 2003; Gerhart, Rynes, \& Fulmer, 2009; Rynes, Gerhart, \& Parks, 2005). Incentive effects represent the influence of PFP plans through employee motivation, based on the premise that PFP plans can increase employee motivation and hence employee performance. Sorting effects alter the composition of the workforce, in that PFP plans can affect the quality of workers who apply for jobs (Lazear, 1986; Rynes et al., 2005) and the performance level of those leaving the organization (Salamin \& Hom, 2005; Shaw \& Gupta, 2007; Trevor, Gerhart, \& Boudreau, 1997). While there are still some examples of ineffective PFP plans (e.g., Beer \& Cannon, 2004; Kahn \& Sherer, 1990; Lawler, 2000; Pearce, Stevenson, \& Perry, 1985; Pfeffer, 1998), the preponderance of evidence shows that PFP plans have positive effects (cf., Gerhart \& Fang, 2014; Gerhart et al., 2009). Yet, even with a substantial body of research discussing the effects of particular PFP interventions, PFP research has typically failed to consider the complex, multi-plan environments in which many organizations invest and many employees face (Gerhart et al., 2009; Rynes et al., 2005). This lack of consideration of more multifaceted environments presents a theoretical gap for understanding and testing how relevant PFP theories apply in more complex environments, and a practical gap for organizations needing to predict the sort of effects they should expect from their multi-plan environments. 
While the literature on PFP plans is quite extensive (for reviews, see Gerhart \& Fang, 2014; Gerhart et al., 2009; Guthrie, 2007; Rynes et al., 2005), prior PFP research is largely based on specific examinations of individual PFP plans. Most studies examine a single form of PFP at a time, particularly in laboratory studies (e.g., Bandiera, Barankay, \& Rasul, 2007; Cadsby et al., 2007; Eisenberger, Rhoades, \& Cameron, 1999; Kwong \& Wong, 2014), but also in organizational settings (e.g., Banker, Lee, Potter, \& Srinivasan, 1996, 2001; Dunford, Boudreau, \& Boswell, 2005; Eisenberger et al., 1999; Pearce et al., 1985; Schaubroeck, Shaw, Duffy, \& Mitra, 2008). Other work provides only broad overviews of PFP plans' effects, such as in strategic HR management research which typically asks general questions about the extent to which employees are covered by PFP (e.g., Bhattacharya, Gibson, \& Doty, 2005; Delery \& Doty, 1996; Gerhart \& Milkovich, 1992; Toh, Morgeson, \& Campion, 2008; Wright, Gardner, Moynihan, \& Allen, 2005). This previous work has certainly been valuable for providing information on the nature of PFP effects; however, the generalizability of theory and findings from single-plan focal studies to multi-plan environments is questionable.

Many companies use multiple types of PFP simultaneously (Cohen, 2011; Gerhart \& Fang, 2014; Gerhart, et al., 2009; Rynes et al., 2005). A 2010 WorldatWork Survey showed that $92 \%$ of companies use merit raises, $80 \%$ provide some form of individual-based variable pay program (not including sales commissions or merit raises), and 57\% use some sort of performance-sharing plan. The same survey conducted in 2012 (WorldatWork, 2012) showed this to be an increasing trend, with $95 \%$ offering merit pay, $84 \%$ with some form of individualbased variable pay program, and 58\% using some form of performance-sharing. While these surveys do not explicitly report the number of different incentive plans covering the same employees, mathematically, we can extrapolate that at least three-quarters of companies use at 
least two forms of PFP, and over one quarter are simultaneously using three different PFP plans. Despite this prevalent complexity, though, there is minimal research considering the relative effectiveness of different PFP plans.

Studying PFP explicitly within the more complex environment of multiple PFP plans is critical in order to gain a better understanding of the relative effectiveness of different PFP forms. This study makes several contributions to our understanding of the effectiveness of PFP. First, this study considers multiple PFP plans simultaneously in multi-PFP plan environments. As noted above, most prior PFP research has considered a single PFP plan at a time, with it either being explicitly on a single plan, or unstated or unexplored if other PFP plans were operating simultaneously. It is unclear whether the predictions for individual PFP plans would generalize when it is explicitly known that other PFP plans are in operation. Furthermore, by applying PFP-related theories to the context of multiple PFP plans, we are examining a previously unexplored set of processes. It is not immediately evident what the effects of one PFP plan would be after controlling for the effects of other PFP plans, especially if the plans have related effects. This study extends PFP theories to consider the context of multiple PFP environments, where a portfolio of PFP plans cover employees.

Second, we contribute to the compensation literature by considering a gap between research and practice. Practically, we inform managers about how different PFP plans should be combined to increase employee performance in their organizations. It is clear that organizations are investing significant sums of money into multiple PFP forms (WorldatWork, 2010, 2012). With a sizable and growing number of employees being covered by two or more PFP plans, the lack of research on the relative effectiveness of such plans represents a notable gap in applicable research knowledge. While many argue that practitioners should take an evidence-based 
approach to management policy (e.g., Rousseau, 2006; Rousseau \& McCarthy, 2007), the lack of research addressing this specific situation represents another notable disconnect between research and practice (e.g., Cascio \& Aguinis, 2008; Rynes, Giluk, \& Brown, 2007), a particular problem in the area of compensation (Deadrick \& Gibson, 2007; Rynes et al., 2007).

The purpose of this paper is to apply existing PFP-relevant theory to differentiate between the effects of multiple PFP plans implemented simultaneously. We propose that a structural approach to understanding PFP plans can be used to form predictions on the relative effectiveness of different PFP plans for both incentive effects and sorting effects. By considering the specific characteristics of PFP plans, we can build theory to predict not just the general (directional) effects of PFP plans, but the relative effectiveness of plans. Furthermore, we can extend theory to the purpose of considering the simultaneous effects of multiple PFP plans.

\section{A STRUCTURAL APPROACH TO COMPENSATION PLANS}

Multiple types of PFP plans are often used through a combination of individual-based rewards (e.g., merit pay, lump-sum bonuses, and individual incentives) and/or group-based rewards (e.g., gain-sharing, profit sharing) (Gerhart et al., 2009; Milkovich et al., 2013). Every pay form has advantages and disadvantages, and these programs should differ in terms of both their incentive and sorting effects (Gerhart et al., 2009). What makes the study of compensation systems complex is that some aspects of PFP plans are different by definition (e.g., the reward is permanent, a one-time payment, or will take time before the reward is vested), while other characteristics can vary both within and across plan types (e.g., the strength of the relationship between performance and rewards, the award size). While prior use of theories regarding a single type of plan has typically yielded general predictions that PFP plans should have positive effects, such a holistic approach misses important characteristics of PFP plans and has questionable (or, 
at least untested) generalizability to considering the simultaneous effects of multiple PFP plans. Based on pay plans' mechanisms, we can differentiate between pay form and functionality, which can vary depending on different pay practices, thus delineating where hypotheses can be created based on the type of PFP being provided (i.e., pay plan definition, or form) and those based on the specific characteristics of the PFP plan (i.e., pay plan functionality).

\section{What's In a Name Anyhow: The Effect of Different Pay Forms}

PFP plans come in a variety of forms, both in terms of the level of the performance metric (e.g., individual, team, unit) and the type of award it provides (e.g., recognition, nonmonetary awards, lump-sum cash awards, long-term incentives (LTI), and permanent pay increases). It is beyond the scope of any one study to contrast every potential PFP plan, and so we begin to address the noted gap in compensation research by considering three increasingly common PFP plans: merit pay, individual-based annual performance bonuses, and LTI. The first two of these are individually based and rewarded; the third is awarded to an individual and the size of the award depends in part on individual performance, but ultimately the value of the award depends on the overall market performance of the organization and vesting requirements.

Merit pay is a form of reward in which individuals receive permanent pay increases (i.e., raises) as a function of their individual performance ratings (Heneman \& Werner, 2005). The pay plan is usually based on an individual's performance, assessed by an employee performance appraisal (Rynes et al., 2005; Schwab \& Olson, 1990). Merit pay shares elements of both variable pay and fixed pay. It is variable in that the pay raise depends on individual performance, and thus new raises must be re-earned each year. It is fixed, though, in that any given merit raise increases base pay, and thus regardless of future performance levels, that new base pay will continue to be received even if performance changes (barring employee termination). 
Bonus pay is a monetary reward given in addition to employees' fixed compensation (Milkovich et al., 2013). Bonuses are ostensibly based on individual performance but do not increase employees' base pay (Sturman \& Short, 2000). This type of pay plan has been widely used in organizations to motivate employees' performance, and surveys report that the popularity of bonus pay is increasing (cf., Sturman \& Short, 2000; WorldatWork, 2012). Individual-based performance bonuses are attractive from the company's perspective because the one-time cash rewards link pay to performance but do not increase fixed labor costs (Sturman \& Short, 2000).

LTI are rewards linked to a firm's long-term growth as well as employee retention (Rousseau \& Ho, 2000), generally in the form of cash or stocks (Moynihan, 2013). LTI allow a link between pay and performance, and like bonuses must be re-earned each year. Their rewards, however, are not immediate. Employees must wait until such awards are vested before their value can be used. While companies have historically offered LTI mostly to executives, many firms have begun applying LTI plans to non-executive employees (Core \& Guay, 2001; National Center for Employee Ownership, 2012; Oyer \& Schaefer, 2005). LTI plans are also PFP plans because the award itself may be a function of individual performance, and the value of the incentives change based on the performance of the organization. This helps tie employee rewards to overall organizational performance, although such PFP is no longer solely linked to individual performance.

\section{Getting What You Pay For: The Link Between Pay and Performance}

As reviewed above, a pay plan's name reveals information about its' award, but simply calling something a PFP plan does not necessarily mean it links pay with performance. A number of theories suggest that the strength of the PFP link will lead to beneficial incentive and sorting effects (Lambert, Larcker, \& Weigelt, 1993); thus, the degree to which pay and performance are 
linked is a critical characteristic of any PFP plan (Milkovich et al., 2013; Zenger, 1992).

Expectancy theory proposes that employees make rational decisions based on the characteristics of the incentives they are facing (Bartol \& Durham, 2000; Fusilier, Ganster, \& Middlemist, 1984; Vroom, 1964), hence positing that, all else equal, motivation will be stronger if there is a stronger link between performance and rewards (Bartol \& Durham, 2000; Bonner \& Sprinkle, 2002; Kahn \& Sherer, 1990; Lawler, 1971). Thus, financial rewards that are strongly tied to individual performance increase employees' effort, and this increased effort is supposed to lead to increases in performance (Bonner \& Sprinkle, 2002; Lawler, 1971). Similarly, agency theory predicts that if performance can be monitored and tied to awards, then the rewards system can improve individual performance (Bartol \& Locke, 2000; Eisenhardt, 1989). Agency theory also posits that a strong PFP plan can help solve the risk-sharing problem that organizations often experience in agency relationships by leading people who are highly risk-averse and less productive to leave their jobs (Cadsby et al., 2007; Eisenhardt, 1989). Tournament theory suggests that employees compete for higher rewards, and so a stronger link between performance and rewards should be associated with greater effort to achieve the higher awards (Becker \& Huselid, 1992). At the same time, the competition among individuals attracts high performers but increases voluntary turnover of poor performers (Bloom \& Michel, 2002; Shaw \& Gupta, 2007). Even though some have argued that equity theory is counter to PFP, it has been recognized that equity does not mean equality (Brown, Sturman, \& Simmering, 2003; Trevor, Reilly, \& Gerhart, 2012). To maintain equity across employees, it is necessary to link pay and performance so that individuals' ratios of performance to rewards are maintained across performance levels.

To understand the potentially different effects of PFP plans, we must therefore specifically examine the strengths of the associations between performance and rewards. 
Research has provided examples of widely disparate relationships between pay and performance under nominal PFP plans. For example, research has shown varying relationships between raises and performance under merit plans (e.g., Harris, Gilbreath, \& Sunday, 1998; Kahn \& Sherer, 1990; Markham, 1988). Similarly, some research has examined bonus plans that have only a modest correlation between performance evaluations and bonuses (e.g., r=.15 in Mizruchi, Stearns, \& Fleischer, 2011), where others have shown stronger relationships (e.g., r=.42 in Salamin \& Hom, 2005). Research on LTI has been more limited. One exception (Cappelli \& Conyon, 2011) examined how stock incentives relate to employees' future job performance. In the study, all employees at the same administrative level received the same amount of shares with the same vesting requirements. The results showed that higher profits led individual employees to better performance. This research shows that LTI can influence individual employee performance, but more research is noted to understand how strong this effect is, particularly in relation to other PFP options.

In this study, we consider complex environments where more than a single PFP form is provided. First, we look at incentive effects of multiple PFP plans that have been implemented simultaneously.

\section{Incentive Effects of Pay-for-Performance}

Incentive Effects of PFP Plans, Considered Simultaneously. The fundamental premise behind PFP plans is that by tying pay to higher performance levels, such plans will motivate higher performance. All else equal, and based most directly on expectancy and tournament theory, stronger connections should be associated with greater performance gains. The context of a multiple PFP environment, though, presents an untested theoretical question. In field settings, it is often unclear if a specific PFP plan under consideration was the sole PFP plan or if other PFP 
plans might have been in place. The theory, though, is quite general in its propositions, suggesting that if a given PFP plan creates a link between performance and pay, it should be associated with improved individual performance. While prior findings predicted that each form of PFP should be related to higher performance levels, this has been framed when considering a comparison to a null effect (e.g., Banker et al., 1996; 2001; Lazear, 2000; Pearce et al., 1985) or relative to the other plans (Kahn \& Sherer, 1990; Nyberg, Pieper, \& Trevor, in press)

When we consider the plans simultaneously, the situation is more complex. We cannot simply assume that the incentive effects from all three plans combine linearly, because their effects are not independent. Particularly, if we are considering how pay is tied to performance, the way in which pay and performance are linked may essentially overlap across plans. When considering multiple pay plans, one must therefore consider the independent effects of each pay plan. That is, we must ask: what is the effect of a given PFP plan after controlling for the effects of the other PFP plans that are present? For example, to know the effect of merit pay in a multiPFP environment, we must look at the relationship between merit pay and performance after controlling for the relationships between pay and performance from the other PFP plans. This represents the incentive effects uniquely attributable to the particular PFP plan. Stated in more statistical terms, this means we are looking at the partialled effects of each pay form: the relationship between pay and performance for a given pay form after controlling for the effects of the relationship between pay and performance for all other pay forms. When considering multiple PFP plans simultaneously, we only expect a given PFP plan to have an effect if the plan still has a relationship with performance after controlling for the relationships from the other pay forms. Hence, we predict:

Hypothesis 1: When considering the incentive effects of multiple pay plans 
simultaneously, the strength of the connection between individual performance and associated rewards, after separating the PFP effects (i.e., controlling for effects) associated with other pay plans, will be positively related to future employee performance.

Relative Effects of PFP Plans, Considered Simultaneously. Prior research has paid little attention to the valence (i.e., the attractiveness of rewards) of the monetary awards across PFP plans (cf., Gerhart, Minkoff \& Olsen, 1995). Yet, with the multiple pay forms that are the focus of this study—merit pay, bonuses, and LTI—one cannot assume that valences are equal. Individuals should value rewards differently due to their particular characteristics. With unequal valences, the incentive effects of different pay plans should likewise be unequal.

The theories reviewed earlier have essentially the same key take-away: that more is better. As has been most typically applied, that "more" has been considered within the context of a single pay form; yet, the same basic concept would seem to apply if there are multiple pay forms. Expectancy theory would predict that if one is covered by multiple pay plans, and assuming the plans operated independently (i.e., each relationship between pay and performance effect was independent of the other PFP relationships) and the valences for those pay plans were equal (i.e., the rewards from each plan were valued equally), the motivational effects from multiple pay plans should be cumulative. For considering multiple pay plans, however, such simplifications are unlikely. This is due to two fundamental issues that must be considered to form hypotheses regarding multiple pay forms: the different levels of valence across plans, and the non-independence of PFP relationships across plans.

While there certainly may be individual differences with regard to pay preferences and valence (Mitchell \& Mickel, 1999), all else being equal, a larger reward should be perceived 
more positively than a smaller reward. Similarly, individuals' preferences for rewards are a function of delay (i.e., immediate versus delayed rewards) and risk. According to decisionmaking literature, future uncertain rewards are less valued than immediate assured rewards (Green \& Myerson, 2004; Steel \& Konig, 2006). Immediate rewards should be perceived more positively than a future reward of the same amount. Likewise, a guaranteed reward should be perceived more positively than a risky reward. Steel and Konig (2006) addressed that individuals are more likely to value immediate but smaller rewards than large but distant ones when they need to choose some behaviors that lead to rewards. Indeed, people tend to undervalue future events. Thus, the three pay plan types we are examining — merit pay, bonuses, and LTI—clearly differ with regard to their value, immediacy, and risk. The objective characteristics of the rewards can, depending on individual differences, be interpreted as the attractiveness of the rewards (valence).

A key characteristic of merit pay is that it permanently increases employees' base pay. Although new merit raises have to be re-earned each year, once a raise is given, the individual will continue to receive that reward as long as the individual remains with the organization. This characteristic differentiates merit pay from the other forms of PFP that we discuss. Bonuses are one-time payments, and thus do not change an individual's level of base pay (Sturman \& Short, 2000). As a one-time payment, the economic value of a bonus is always less than that of a raise for any person staying beyond one year. Due to the characteristics of merit pay, the permanent increase from merit pay has a greater lifetime value than the one-time rewards granted by other pay plans (Shaw, Duffy, Mitra, Lockhart, \& Bowler, 2003). Whether from an expectancy theory perspective based on the idea that a permanent increase has greater valence than a one-time payment, or from a tournament theory perspective stemming from a raise constituting a larger 
pay differential than a bonus, on a unit-per-unit basis (e.g., a $\$ 1$ raise versus a $\$ 1$ bonus), the incentive effect for merit pay should be greater than the incentive effect for bonuses.

LTI represent one-time payments; however, while bonuses are immediate payments, LTI are not. LTI require a vesting period (cf., Dunford, Oler, \& Boudreau, 2008) and so are not immediately liquid. Stock awards are also more risky, as the value of the award can fluctuate with time and even become zero (Hull, 2012). As noted earlier, all else equal, individuals typically prefer immediate rewards to delayed rewards (e.g., Green \& Myerson, 2004). In addition, the liquidity of cash bonuses causes such rewards, on a dollar-per-dollar basis, to have a greater present value than a comparably sized stock award. Together, these characteristics indicate a lower valence for LTI than both raises and bonuses. Note, though, that we are not examining group-level outcomes. It may indeed be true that LTI more effectively influences group-level outcomes than more individually-oriented PFP plans. This question, though, is beyond the scope of our paper, although it is certainly an interesting potential area for future research. Thus, we predict:

Hypothesis 2: If the separated PFP relationship (i.e., the effects for each plan, after controlling for the PFP effects of the other plans) for each plan has effects (is greater than zero), the incentive effect for merit pay on individual job performance should be greater than the incentive effect for bonuses, which should be greater than the incentive effect for LTI.

However, if the PFP relationship for any pay form is zero after controlling for the effects of the other pay plans, then regardless of the pay form, the effect of that PFP relationship should be unrelated to performance. Thus, we predict

Hypothesis 3: For any plan type where the separated PFP relationship (i.e., the effect of the plan, after controlling for the PFP effects of the other plans) has no effects (is not 
significantly different from zero), the incentive effect of the connection between pay and performance for that plan on individual job performance should be zero.

\section{Sorting Effects of Pay-for-Performance}

Sorting Effects of PFP Plans, Considered Simultaneously. In addition to incentive effects, PFP plans can play an important role in attracting and retaining highly productive employees (Bartol \& Durham, 2000; Gerhart \& Fang, 2014). Research has shown that the relationship between performance and turnover is curvilinear, such that high performers and low performers are most likely to leave an organization (Salamin \& Hom, 2005; Sturman, Shao, \& Katz, 2012; Trevor et al., 1997). A higher PFP relationship, however, should decrease highperformer turnover because the high reward contingency leads to lower desirability of movement (e.g., Allen \& Griffeth, 2001; Jackofsky, Ferris, \& Breckenridge, 1986; Trevor et al., 1997). Empirical research specifically into how different forms of PFP influence sorting effects, though, is limited (Gerhart et al., 2009). Trevor et al. (1997) looked at mean salary growth over a four-year period. They found that higher salary growth reduced the overall likelihood of turnover and the turnover of high performers. Similarly, Salamin and Hom (2005) looked at individuals' mean pay increase and latest bonus as moderators of the performance-turnover relationship. They found that bonuses reduced the probability of turnover. In contrast to Trevor et al. (1997), though, Salamin and Hom (2005) found that raises had no significant effect on how performance related to turnover.

Both Trevor et al. (1997) and Salamin and Hom (2005) considered how pay influences the effect of performance on turnover; they did not, however, specifically consider how strongly pay and performance were linked. In Trevor et al. (2007), the correlation between performance and average salary growth was 0.30. In Salamin and Hom (2005), the correlation between the 
mean pay increase and performance was only 0.05 , whereas the correlation between performance and the latest bonus was 0.42 . Thus, the discrepant results associated with pay increases between these two studies may be due to the different strengths of the connection between pay and performance (Zenger, 1992). In both studies, when there was a higher correlation between pay and performance (i.e., 0.30 or 0.42 ), the pay system did improve retention of high performers.

Research on LTI is more limited. Some research on executive compensation has shown that stock awards and other LTI are associated with reduced turnover (e.g., Batt \& Colvin, 2011; Mehran \& Yermack, 1996). Other research has examined the how repricing underwater stock options influences turnover (e.g., Carter \& Lynch 2004; Daily, Certo, \& Dalton, 2002; Dunford et al. 2005). No research has yet addressed if LTI affects the performance-turnover relationship.

Research also has yet to specifically examine the degree to which a PFP link for multiple types of pay forms influences individual turnover. Relevant theory, however, can provide some insights into the nature of the sorting effects that we might expect. Tying pay to performance should reduce the desirability of turnover for high performers (Allen \& Griffeth, 2001; Salamin \& Hom, 2005; Schwab, 1991; Trevor, et al., 1997; Williams, 1999). The degree of this contingency should moderate the relationship between performance and desirability of movement. This prediction held in instances when raises (Trevor et al., 1997) and bonuses (Salamin \& Hom, 2005) were related to performance, but not when raises were unrelated to performance (Salamin \& Hom, 2005). Thus, we expect that PFP, no matter what the form, should help reduce the probability of high-performer turnover, but also that the nature of the reward (raise, bonus, or LTI) makes relative differences in PFP effectiveness. It is again more complex to consider multiple plans operating simultaneously.

The way PFP influences turnover is based on the supposition that it moderates the 
relationship between performance and the desirability of turnover (Allen \& Griffeth, 2001). This is based more on theories of equity and fairness than expectancy. As such, partialling out the relationship between pay and performance should not necessarily have the same effect on turnover as it does on performance. We still expect that each PFP plan will have an effect on reducing employee voluntary turnover when considered simultaneously because, to the extent that each plan links pay and performance, each plan is reinforcing the equity relationship that high outputs (performance) are tied to high inputs (rewards).

The enduring nature of merit pay indicates a potentially strong sorting effect. Because a raise has a permanent effect on base pay, once it is earned in a given year, it will be repeatedly earned, even if performance declines. Furthermore, current raises can lead to more future value because raises are compounded. That is, as raises are typically expressed as a percent of salary (Milkovich et al., 2013), a raise creates more value for future raises. It may also make future bonuses and LTI larger if they are based on the size of the individual's salary. Thus, in comparison to a one-time bonus or LTI, a raise should have the greatest potential for retaining employees in contrast to a comparably-sized bonus or LTI. We therefore predict

Hypothesis 4: When considering merit pay, bonuses, and LTI plans simultaneously, the PFP for merit pay will negatively moderate the performance-turnover relationship.

While we again predict the strongest effect for merit pay, the sorting effects of bonuses versus LTI should differ from their incentive effects. A key purpose of deferring compensation is to foster employee retention (e.g., Core \& Guay, 2001; Jones \& Kato, 1995; Oyer \& Schaefer, 2005). Providing LTI increases the cost of turnover for employees because leaving the organization requires them to forfeit any rewards that are not vested. Thus, we predict Hypothesis 5: When considering merit pay, bonuses, and LTI plans simultaneously, the 
PFP for LTI will negatively moderate the performance-turnover relationship.

Relative Effects of PFP Plans, Considered Simultaneously. Both merit pay and LTI, by

increasing the cost of turnover, should reduce the likelihood of high-performance turnover. Yet because a merit pay award has greater value than an equally sized LTI award, we again expect merit pay to have a stronger effect. We therefore predict

Hypothesis 6: When considering merit pay, bonuses, and LTI plans simultaneously, the effect of PFP on the performance-turnover relationship will be stronger (i.e., more negative) for merit pay than for LTI.

The nature of bonuses, though, makes their effects less clear. This is because bonuses have characteristics which both decrease the desirability of movement but increase the ease of movement. By having a connection between pay and performance, bonuses will increase equity and fairness perceptions of high performers, thus decreasing the desirability of movement. At the same time, the large monetary influx from a large bonus may actually increase the individual's ease of movement. This can occur because either (1) the monetary reserves make leaving one job and finding another more feasible, or (2) if the individual had an intent to leave, was a high performer, and was expecting a large bonus, it would be most logical to wait for the bonus before leaving the position. Consistent with this, Sturman and Short (2000) showed that bonus satisfaction was negatively related to intent to turnover when not considering other aspects of pay satisfaction or other attitudes; however, after controlling for the other pay satisfaction dimensions (including for raises), bonuses actually had a positive effect on intent-to-turnover. Thus, because bonuses seemingly can create both incentives and disincentives for turnover when considered simultaneously with other PFP plans, we have no a priori hypotheses regarding their effects when considered in conjunction with merit raises and LTI. 


\section{METHOD}

\section{Sample}

The data for this study were obtained from a large service-related company that was a subsidiary of a larger, diversified publicly traded American corporation. The company which is the focus of our study offers broad-based business services to companies in the global travel industry, providing technology and support to global travel companies and managing technology related to online travel. The business thus focuses on issues of technology and pricing, but has positions in account sales and service, accounting, customer training and support, finance, human resources, legal, marketing and communications, and product and technology development. The company provided data on performance ratings, gender, organization tenure, salary, and percentage of three financial rewards (merit pay, bonuses, and LTI) associated with 2001 and 2002. We only examined employees who had performance ratings in 2001 , did not leave involuntarily in 2002, and were eligible for all three forms of compensation. This resulted in an original potential sample of 900 employees from 17 locations in the U.S. All positions were white-collar, exempt, full-time, and required a college degree. The most common job titles were Developer, Senior Developer, Systems Engineer, Travel Supervisor, Account Manager, and Project Manager.

It should also be noted that the references to the calendar year are not entirely precise in that they refer to the relevant time period and not the date of the award or decision. Performance reviews in a given year are intended to reflect the individual's performance for that calendar year (so, the 2001 performance rating is designed to capture performance during the 2001 year, but was determined in early 2002). Compensation awards associated with a given year reflect the award of each type given for that year. Thus, the 2001 bonus is actually awarded in 2002, but is 
awarded to the individual for service over the 2001 year. Similarly, the 2001 raise is awarded in early 2002, as is the 2001 LTI. We refer to 2001 rewards to represent the awards associated with 2001 performance. Note that 2001 salary, though, was the salary at the beginning of 2001 .

To provide an estimate of the PFP relationships for each employee (as will be explained in greater detail below), we calculated the relationship that existed between 2001 performance and each resultant form of compensation for 2001 performance under each supervisor. Thus, we eliminated all individuals in the sample who did not have the same supervisor in both 2001 and 2002 and (for the purposes of being able to compute PFP relationships for each supervisor, as we will explain below) all employees under supervisors who did not have at least 3 subordinates. This resulted in a sample of 720 employees under 88 supervisors. Supervisors had an average of 8.1 subordinates $(\mathrm{SD}=7.58$; range $=3-59)$. For predicting 2002 performance, we eliminated subjects who left the organization (and thus did not have 2002 performance ratings), resulting in a sample of 635 employees (also under 88 supervisors).

\section{Organizational Compensation System}

The organization provided guidance to supervisors regarding the allocation of compensation, but supervisors had discretion in the allocation decisions. This is a typical approach used by many organizations for their PFP plans (cf., WorldatWork, 2012). For merit pay, a range of percent pay increases were specified for each performance rating category. Supervisors had discretion regarding what the specific raise should be within this range.

The company paid bonuses, which reflected the judgment of the supervisor based on the individual's performance rating and the individual's position. Each position had a bonus target, based on its degree of responsibility. Organizational performance affected the amount of total rewards that would be distributed, a decision made by executives within the organization (not in 
our sample). Supervisors were given a budget with which to allocate rewards to their subordinates. They were instructed to use the bonus target and individual performance to guide their decisions, but had discretion with regard to how actual distributions were made. Managers did not have complete discretion, though, in that all pay decisions were ultimately approved by the human resources department.

The distribution of LTI was based on both organizational performance (which determined the budget for this award) and individual job performance, although the dollar value of actual awards was also affected by the performance of the company's stock. Each year, the company distributed restricted stock units to their employees based on individual performance and criticality of employees' job positions. At the time of the award, the restricted stock had no real market value. Rather, these stock grants would, at a future vesting date, "turn into" actual shares of the company's real stock. In other words, when granted, the restricted stock had no immediately realizable monetary value (although it was expressed as such, based on the number of shares and its current price). The company used a five-year gradual vesting schedule, with $20 \%$ of the stocks becoming vested each year (and the value of that award constituting income). Once vested, the award had the same market value as any other share of common stock from the organization. Over the span of this study, the value of company stock did vary, but increased an average of $1.08 \%$ per month. Employees of the company were educated about the financial rewards system via intranet, written communication, and training workshops.

\section{Measures}

Employee job performance. Employee job performance ratings from 2001 and 2002 were used as independent and dependent variables. The ratings used a 4-point scale: significantly exceeds expectations, exceeds expectations, meets expectations, and below expectations. The 
ratings were transformed to indicator variables from 1 (lowest performance) to 4 (highest performance). The company used "management by objectives" to create performance ratings, and significant time is allocated by the organization for these purposes.

For predicting turnover, we needed to examine potential non-linear effects of performance (Salamin \& Hom, 2005; Sturman et al., 2012; Trevor et al., 1997). For these analyses, we considered both a linear effect, computed as a mean-centered measure of 2001 performance, and a quadratic effect. Because we wanted to specifically differentiate between linear and non-linear effects, we needed to ensure that the two terms were orthogonal. Although mean-centering (cf., Aiken \& West, 1991) is common and can reduce the correlation between linear and squared terms, it does not yield orthogonal terms. Indeed, in this case, mean centering would still result in the linear and quadratic terms being correlated 0.21 . We therefore used residual-centering (Lance, 1988). That is, we regressed the squared term on the linear term and used the residual to represent the quadratic effect. This residual is uncorrelated with the linear term but captures the non-linearity associated with the squared term (Lance, 1988). Residualcentering has been shown to be effective in cases like this one, in which (1) the main and quadratic effects are correlated, (2) sample sizes are moderate to large, and (3) decomposition of the effects is desired (Lance, 1988).

Measuring the Pay-for-Performance Relationships. To test our hypotheses, we needed a measure of the link between pay and performance for the three compensation plans. Prior compensation research has examined this by looking at the reward received (e.g., the change in pay or total compensation) divided by the performance score (e.g., a given dollar change in share-holder value or firm return) (e.g., Hall \& Knox, 2004; Hayes, 2004) or by calculating the derivative of pay with respect to performance (e.g., Kahn \& Sherer, 1990). The former approach 
is not ideal for our study, as it is simply an individual's ratio and does not directly capture a relationship between pay and performance. It is unclear if effects from such ratios are due to the numerator, denominator, or the hypothesized combination of the two. It also does not capture if indeed there is a pattern of pay and performance effects across individuals (which is what PFP plans are purported to have). The approach of calculating a derivative (e.g., Kahn \& Sherer, 1990) more directly assesses if there is a relationship between performance and pay, but the approach is based on looking at effects associated with interactions with performance scores (because if there is a straightforward relationship between pay and performance, this becomes a constant that is equal across subjects). We wanted to more directly assess exactly how pay and performance are related to each other within groups that should share a similar effect. To estimate this relationship for each employee, we therefore examined the strength of the link between pay and performance under each supervisor.

For each supervisor (as noted above, with at least 3 subordinates), we computed the three regression coefficients that estimated the relationships between 2001 performance and the three forms of 2001 rewards. For each supervisor and pay form, the percent reward was regressed on the employee performance rating. Rewards were presented as percentage points (so $1=1 \%$ ), and the raw rating metric (1-4) was used as the independent variable. For each pay form, we thus ran 88 regressions. This yielded $88 \mathrm{~B}$ coefficients associated with each of the three PFP relationships, which we labeled PFP-Merit, PFP-Bonus, and PFP-LTI.

It should be noted that, for subsequent analyses, our PFP metrics were not independent. That is, individual observations of PFP were not fully independent because employees under the same supervisor operated under the same PFP relationship. We thus needed to use multi-level modeling (Raudenbush \& Bryk, 2002) when considering the PFP effects of the various plans. 
This approach to measuring PFP, while new, has a number of advantages. Most notably, it directly assesses the simple and straightforward relationship that exists between pay and performance for each pay form, which matches the measure to the theoretical premise better than other PFP measures have done. Note also that this approach does not require us to assume that individuals know what others get paid. If a supervisor has a strong PFP relationship, a low performer will see a low reward and a high performer will see a higher reward (which is similar to what a ratio score would yield). If the supervisor has no relationship between pay and performance, this measure will yield a zero as opposed to a ratio score what would yield a high value for a low performer and low value for a high performer. Although individuals may or may not know what others receive, people are likely aware of what typical awards are, either in the company overall or in the economy. A measure of slope (which is what our measure is) thus does not suffer from as much random variance that can occur with ratio scores, even without necessarily assuming that individuals know the performance and rewards of their peers. It should also be noted that this metric has very practical benefits. As an objective measure of PFP, it captures the actual relationship that exists between pay and performance, which is something that can be influenced by organizational policy. It is also a measure that companies can calculate using archival data, and thus allows organizations to critically evaluate their current PFP plans.

Voluntary turnover. Voluntary turnover included departures from the company during 2002. One concern in turnover research is that some previous research has failed to distinguish between voluntary turnover and involuntary turnover (Gardner, Wright, \& Moynihan, 2011; Gerhart, 1990; Wright \& Cropanzano, 1998). Fortunately, the company provided specific information which distinguished between voluntary and involuntary turnover. Thus, we only considered voluntary turnover. In the sample, 85 (12\%) of the 720 employees voluntarily left the 
company. We used a " 0 " to indicate that an employee stayed with the company and a " 1 " to indicate voluntary turnover (although it was treated in most analyses as a categorical variable).

Control variables. Because this study examined the effect of financial rewards on employees' future performance, previous performance (i.e., 2001 job performance rating) was used as a control variable. Using prior performance as a control variable helps partial out the effects of stable characteristics that caused employees' performance (Sturman, 2003; Sturman, Cheramie, \& Cashen, 2005) and unmeasured effects that are attributable to omitted factors (e.g., ability, job knowledge, motivation levels, or opportunities to perform) that might affect performance and pay (Kahn \& Sherer, 1990; Sturman, 2007). While performance ratings certainly are not perfect measures (Viswesvaran, Ones, \& Schmidt, 1996), its inclusion does help address the alternative explanation that high performers get rewarded but also remain high performers. We want to know what affect PFP has beyond knowing that, in general, past performance is the best predictor of future performance (Sturman et al., 2005).

Organization tenure was used as a control variable because it could interfere with testing the main effects of the different characteristics of financial rewards on future performance (Sturman, 2003). Gender differences have been considered a potentially important factor causing pay differences (Milkovich et al., 2013), and so were also controlled for (with men coded as 0, and women coded as 1). Additionally, salary from 2001 was controlled in this study, as was the level of the most recent raise, bonus, and LTI. Because the salary data was skewed, we used a $\log$ transformation to reduce the leverage of high values. The raise, bonus, and LTI were expressed as a percent of salary (before log transformation).

\section{Analyses}

Before we test our hypotheses, we wanted to replicate prior findings and thus see if our 
sample provides similar results to prior research. Our analyses are thus conducted in a series of steps. First, we create a baseline model without PFP variables, to serve as a point of reference (Model 1). We then run a series of models in which we consider a single pay plan at a time. This allows us to replicate prior research which has examined a single pay plan at a time but did not consider if other PFP plans were in effect. Thus, we run a model examining merit pay (Model 2a), bonuses (Model 2b), and LTI (Model 2c). Then, we test our hypotheses with the model which includes all three plans simultaneously (Model 3).

Incentive Effects. In all of our models, because individuals were nested within supervisors, we used hierarchical linear modeling (Raudenbush \& Bryk, 2002) using the HLM7 statistical package (Raudenbush, Bryk, Cheong, Congdon, \& du Toit, 2011). To test the incentive effects of independent PFP plans and relative effects of different PFP plans, our dependent variable was 2002 job performance. The level-1 model we used was:

$$
\begin{gathered}
\text { Perf }_{2002}=\mathrm{B}_{00}+\mathrm{B}_{1} * \operatorname{Perf}_{2001}+\mathrm{B}_{2} * \text { Gender }+\mathrm{B}_{3} * \text { Tenure } \\
+\mathrm{B}_{4} * \ln (\text { Salary } 2001)+\mathrm{B}_{5} * \text { Merit } \%+\mathrm{B}_{6} * \text { Bonus } \%+\mathrm{B}_{7} * \mathrm{LTI} \%+\varepsilon
\end{gathered}
$$

In this model, the intercept $\left(\mathrm{B}_{00}\right)$ was modeled as a random effect.

The second level of analyses varied depending on what type of PFP plans we tested. As noted above, we first examine each PFP plan separately. Thus, the PFP effect for each pay form was entered as the sole level-2 variable. So, to test the effect of merit pay (Model 2a), the level-2 equation was

$$
\mathrm{B}_{00}=\mathrm{G}_{00}+\mathrm{G}_{01} * \text { PFP-Merit }+\xi
$$

whereas to test the effect of bonus pay (Model 2b), the level-2 equation was

$$
\mathrm{B}_{00}=\mathrm{G}_{00}+\mathrm{G}_{01} * \text { PFP-Bonus }+\xi
$$

and to test the effect of LTI (Model 2c), the level-2 equation was 


$$
\mathrm{B}_{00}=\mathrm{G}_{00}+\mathrm{G}_{01} * \text { PFP-LTI }+\xi
$$

To test our hypotheses related to incentive effects of all three plans simultaneously (Model 3), the level-2 equation was

$$
\mathrm{B}_{00}=\mathrm{G}_{00}+\mathrm{G}_{01} * \text { PFP-Merit }+\mathrm{G}_{02} * \text { PFP-Bonus }+\mathrm{G}_{03} * \text { PFP-LTI }+\xi
$$

Sorting Effects. For assessing sorting effects, because turnover is a dichotomous

variable, we used the Bernoulli model in HLM. Thus, our analyses are multi-level but analogous to logistic regression (Raudenbush \& Bryk, 2002). For our test of independent sorting effects, our level-1 model was as follows:

$$
\begin{gathered}
\text { Prob(turnover })=\mathrm{B}_{00}+\mathrm{B}_{10} * \operatorname{Perf}_{2001}+\mathrm{B}_{20} * \operatorname{Perf}^{2}{ }_{2001}+\mathrm{B}_{3} * \text { Gender }+\mathrm{B}_{4} * \text { Tenure } \\
+\mathrm{B}_{5} * \ln (\text { Salary } 2001)+\mathrm{B}_{6} * \text { Merit } \%+\mathrm{B}_{7} * \mathrm{~B}_{0} \text { unus } \%+\mathrm{B}_{8} * \mathrm{LTI} \%+\varepsilon
\end{gathered}
$$

For this model, the intercept and the effects of performance could potentially vary across supervisors, as these coefficients could be affected by the degree of PFP resulting from each supervisor's decisions. Testing revealed, though, that there was only significant level-2 variance for the intercept term; for $\mathrm{B}_{10}$ and $\mathrm{B}_{20}$, the variance component was not significant (at $\mathrm{p}>.50$ ). Thus, only the intercept was modeled as a random effect. Nonetheless, for all three of these coefficients, the level-2 equations were equivalent to Equation $2 \mathrm{a} 2 \mathrm{~b}$, and $2 \mathrm{c}$ above, with the key differences being (1) that there are three equations, with the dependent variables being $\mathrm{B}_{00}, \mathrm{~B}_{10}$, and $\mathrm{B}_{20}$, and (2) that there was no level-2 error term in the equations predicting $\mathrm{B}_{10}$ and $\mathrm{B}_{20}$. Thus, to test the hypotheses related to sorting effects, the level 2 equations were as follows:

$$
\begin{gathered}
\mathrm{B}_{00}=\mathrm{G}_{00}+\mathrm{G}_{01} * \text { PFP-Merit }+\mathrm{G}_{02} * \text { PFP-Bonus }+\mathrm{G}_{03} * \text { PFP-LTI }+\xi \\
\mathrm{B}_{10}=\mathrm{G}_{00}+\mathrm{G}_{01} * \text { PFP-Merit }+\mathrm{G}_{02} * \text { PFP-Bonus }+\mathrm{G}_{03} * \text { PFP-LTI } \\
\mathrm{B}_{20}=\mathrm{G}_{00}+\mathrm{G}_{01} * \text { PFP-Merit }+\mathrm{G}_{02} * \text { PFP-Bonus }+\mathrm{G}_{03} * \text { PFP-LTI }
\end{gathered}
$$




\section{RESULTS}

Summary statistics are presented in Tables 1 and 2 . Table 1 presents the summary statistics for the portion of the sample $(\mathrm{N}=635)$ used in the analyses predicting job performance; Table 2 presents the summary statistics for the sample used in the prediction of turnover $(\mathrm{N}=$ 720). Note that the means of merit $\%$, bonus\%, and LTI\% (shown in Table 2) were $3.08 \%$, $7.02 \%$, and $1.19 \%$ respectively. Thus, the average additional compensation received by employees was $11.29 \%$, although only $3.08 \%$ was an increase in base pay.

Insert Table 1 and 2 about here

For merit pay, across the four performance ratings, the average pay increases were $1.9 \%$ (below expectations), $2.8 \%$ (average performance), 3.3\% (exceeding expectations), and $4.6 \%$ (far exceeding expectations). These levels are similar to the average merit increases in these or similar performance categories reported by Gerhart and Fang (2014). The mean PFP relationship for merit pay was $0.62(\mathrm{SD}=0.14)$ and ranged from 0 to 0.95 ; for bonuses, the mean was 0.73 $(\mathrm{SD}=1.9)$ and ranged from -1.1 to 10.5 ; and for LTI, the mean was $0.57(\mathrm{SD}=1.48)$ and ranged from 0.02 to 9.2. This means, for example, a one-point increase in performance was associated with, on average, a 0.62 percentage point higher raise. The average raise for a high performer (4) is thus 1.86 percentage points higher than that for low performer (1). For some supervisors, larger bonuses were actually granted to lower performers, as evidenced by a minimum PFPBonus value of -1.1. However, as noted, the average relationship was 0.73 .

There are also some strong correlations among the PFP variables and the pay amount percent variables. For example, the relationship between PFP-Bonus and PFP-LTI was strong (r $=.73$ ), showing that managers are fairly consistent in how they distribute bonuses and LTI. Of course, although a high correlation, it still indicates that nearly half the variance between these 
variables is unexplained, and thus there clearly are differences in how managers allocate awards.

Variance components for all models are presented in Table 3 and 4. For both the prediction of 2002 job performance and voluntary turnover, the analyses revealed significant level-2 variance (p's <.05) for the intercepts in the random-intercepts models.

\section{Replicating Previous Findings}

Independent Incentive Effects. Models 2a, 2b, and 2c in Table 3 present the results of the HLM analyses which examine a single pay plan at a time. These results are consistent with existing theory and prior empirical work. Note that these are not nested models, not fully comparable, and thus not used for our hypothesis tests. The purpose of these models is to illustrate what the results would look like if a researcher were examining a single PFP plan at a time in a multi-PFP environment. The results show that the strength of a PFP plan's connection between individual performance and rewards is positively related to future employee performance when considering a single PFP plan at a time. As shown in Models 2a, 2b, and 2c (for merit pay, bonuses, and LTI respectively), all three PFP relationships were significantly related to future performance (all at $\mathrm{p}<.001)$.

\section{Insert Table 3 about here}

Independent Sorting Effects. Table 4 presents the analyses predicting 2002 voluntary turnover, and specifically how the strength of the various PFP links influence the performanceturnover relationship. Again, these results show that our sample produces results consistent with prior research.

A model with no level-2 variables (Model 1 in Table 4) showed that performance had the expected negative linear effect $\left(\mathrm{G}_{10}=-0.54 ; \mathrm{p}<.05\right)$ and positive non-linear effect $\left(\mathrm{G}_{20}=0.71 ; \mathrm{p}\right.$ $<.001$ ), thus replicating the predicted inverted U-shape relationship between performance and 
turnover (Salamin and Hom, 2005; Sturman et al., 2012; Trevor et al., 1997; specifically, the probability of turnover was, on average $52 \%, 14 \%, 7 \%$, and $16 \%$ for performance scores 1 to 4 , respectively). Adding the PFP variables to the second level of analysis was likewise consistent with prior research.

Insert Table 4 about here

The results also show that the strength of each plan's PFP link negatively moderated the performance-turnover relationship. As with the replication of the incentive effects, this pertained to considering individual PFP plans separately. As shown in Models 2a, 2b, and 2c of Table 3, if we were studying any single pay plan at a time that was operating in a multi-PFP environment, the effects of the PFP relationships all had negative effects on the linear and/or quadratic performance variables (all at $\mathrm{p}<.05$ ), thus indicating that a stronger PFP relationship was associated with a lower probability of turnover as performance increased. So, as with incentive effects, were this a study about a single PFP plan, we would have yielded conclusions similar to prior research about PFP plans.

\section{Tests of Relative Incentive Effects (Hypotheses 1-3)}

Tests of our hypotheses regarding relative incentive effects are shown in Table 3, supporting our hypotheses. The three hypotheses pertained to considering all three plans simultaneously. Testing these hypotheses involved considered the separating effect of each plan's PFP relationship. This is important because the PFP relationships for the three pay practices are correlated, with a particularly high correlation between PFP for bonuses and PFP for LTI.

We first computed the partial correlation for each of the three PFP variables on 2001 performance (i.e., the correlation between each PFP variable and 2001 performance with the 
effects of the other two PFP variables separated out). We found that, while the raw correlation of each PFP relationship was significantly related to performance, the partial correlation coefficient for merit pay was largest $\left(\mathrm{r}_{\mathrm{My} \cdot \mathrm{B}, \mathrm{L}}=.16\right)$, followed by a smaller but still significant effect for bonuses $\left(\mathrm{r}_{\mathrm{By} \cdot \mathrm{M}, \mathrm{L}}=.09\right)$, and no significant relationship for LTI $\left(\mathrm{r}_{\mathrm{Ly} \cdot \mathrm{M}, \mathrm{B}}=-.04\right)$.

Hypothesis 1 predicted that when considering the incentive effects of multiple pay plans simultaneously, the strength of the connection between individual performance and associated rewards, after separating out the PFP relationship associated with other PFP plans, would be positively related to future employee performance. Therefore, we expected a positive effect in our full model from merit pay and bonuses, but no effect for LTI. Model 3 in Table 3 indeed supports this. The effect for PFP-Merit was significant $(B=88.22, p<.01)$, as is the effect for PFP-Bonus $(B=8.09, \mathrm{p}<.05)$; the effect of LTI was non-significant $(B=-2.06, p=.73)$.

Hypothesis 2 predicted that for each plan with significant separated PFP relationships, the effect for merit pay would be greater than the effect for bonuses, which again was supported (p < .01). Because PFP-LTI had no separated effect, Hypothesis 2 did not pertain to it. Hypothesis 3 predicted that, for any plan type where the separated PFP relationship was zero, which is true here for LTI, the effect of the connection between pay and performance for that plan should be zero. Indeed, as noted above, the effect of PFP-LTI is non-significant $(\mathrm{p}=.73)$.

\section{Tests of Relative Sorting Effects (Hypotheses 4-6)}

The second half of our hypotheses considered the relative sorting effects of PFP plans, and specifically how the strength of the various PFP links would influence the performanceturnover relationship. Model 3 in Table 4 shows the analyses predicting 2002 voluntary turnover and our tests of Hypotheses 4-6.

The three hypotheses considered the effects of all three PFP plans when analyzed 
together. Hypothesis 4 predicted that, when considering merit pay, bonuses, and LTI plans simultaneously, the PFP on employee turnover for merit pay would negatively moderate the performance-turnover relationship. This was supported by a negative effect of PFP-Merit on the linear effect of performance $(\mathrm{p}<.001)$ and a marginally non-significant effect on the quadratic terms $(\mathrm{p}=.095)$. Hypothesis 5 predicted that, when considering merit pay, bonuses, and LTI plans simultaneously, the PFP on employee turnover for LTI pay would negatively moderate the performance-turnover relationship, which was supported by both significant effects on the linear $(\mathrm{p}<.01)$ and quadratic terms $(\mathrm{p}<.001)$. Finally, Hypothesis 6 predicted that when considering merit pay, bonuses, and LTI plans simultaneously, the PFP on turnover would be stronger (i.e., more negative) for merit pay than for LTI. This was supported by the negative effect of PFPMerit being significantly more negative than the effect for LTI on the linear performance term ( $p$ $<.05)$. The effect on the quadratic term was more negative as predicted, although the difference did not approach statistical significance $(\mathrm{p}=.35)$.

As noted earlier, we had no a priori predictions regarding the effect of bonuses when considered simultaneously with merit pay and LTI. Our analyses revealed that, in the analysis with all three PFP effects, bonuses increased the overall probability of turnover through its significant positive effect on the intercept $(\mathrm{p}<.001$; note that merit pay and LTI had significant negative effects). Bonuses had no effect on either the linear or quadratic performance terms.

\section{DISCUSSION}

Prior work on PFP has generally shown positive incentive and sorting effects, yet this work has not explicitly considered what effects we should expect from PFP plans when employees are performing in a multiple PFP plan environment. Considering how different PFP plans operate in the same environment requires us to consider the relative relationships we 
should expect from PFP plans, thus requiring us to add to our theoretical precision (Edwards \& Berry, 2010). It also requires us to consider how the relevant theory is applicable to partialled effects - the sorts of effects we expect for one PFP plan when controlling for the effects of other PFP plans. Our findings show that prior PFP research, which has generally focused on a single plan at a time, generalizes to more complex environments. Furthermore, the predictions of the relative effectiveness of PFP plans from theory generally hold, and hence the expansion of theory to multi-plan environments does have some external validity.

This study provides three general forms of theoretical contributions. The first is the replication and confirmation of the generalizability of prior research. Our results show that prior PFP research - be it on a single-PFP plan or in multi-PFP plan environments but with the other plans not considered-replicates and generalizes to multi-PFP plan environments. The general findings of incentive and sorting effects do hold when considering PFP plans independently, even when other PFP plans are operating but are not controlled for in the analyses.

Second, our results provide a test of the theoretical precision of theories that have been related to PFP plans. Because of the different sorts of rewards associated with different PFP plans, expectancy theory in particular would predict different effects. Expectancy theory remains one of the dominant decision-making theories (Vancouver, Weinhardt, \& Schmidt, 2010), and continues to play an important role in its own right (Cadsby et al., 2007; Gerhart et al., 2009; Kepes, Delery, \& Gupta, 2009) in addition to being incorporated into more sophisticated current theories of motivation (e.g., Schmidt \& DeShon, 2007; Steel \& Konig, 2006; Vancouver et al. 2010). While the internal validity of expectancy theory has generally been supported (i.e. general positive effects found for expectancy, valence, or the interaction; see Van Eerde \& Thierry, 1996), there is far less research testing the external validity of the theory (its ability to make 
accurate predictions in new contexts) or if its tenets hold for predicting the relative effects of expectancy or valence. We do indeed support the applicability of expectancy theory for making such predictions. In the replication, the results show that merit pay is more valuable than a bonus or LTI on a dollar-per-dollar basis, and indeed it has stronger incentive and sorting effects.

Third, we expanded on prior theory to consider the implications of multiple pay plans being implemented simultaneously. While some prior work has analyzed situations with multiple pay plans (Kahn \& Sherer, 1990; Salamin \& Hom, 2005), both of those studies had one pay plan where rewards were unrelated to performance; additionally, these studies did not explicitly consider how multiple pay plans operating simultaneously might be different from plans' independent effects. We specifically predicted and supported that considering partialled effects is important for incentive effects, while not so for sorting effects.

Our study thus provides a theoretically consistent explanation for the mixed results previously observed for merit pay. The effectiveness of merit pay has been repeatedly questioned (Gerhart et al., 2009; Gerhart \& Rynes, 2003; Heneman \& Werner, 2005). A key concern is that differences in awards between the best and the worst performers are often not large (GomezMejia \& Balkin, 1989); others have shown examples where there is actually no relationship between pay and performance in a nominal merit pay plan (e.g., Kahn \& Sherer, 1990). These concerns, though, are not completely generalizable to all implementations of merit pay. Rather, when viewed through the lens of expectancy theory, they suggest that the merit plans are often poorly implemented because they fail to generate a PFP link. Our findings provide a better understanding of the mechanisms that PFP plans should have so as to yield the desired results. Our results show that it is an overgeneralization to suggest there is a single positive effect for any type of PFP plan. Instead, PFP plan effectiveness depends on how strongly pay and performance 
are linked. Furthermore, the practical effects of any pay plan will also depend on the budget for the awards, for without resources, it is difficult to create a plan with a strong PFP link. Thus, while our results showed that merit pay has the strongest effects on performance and turnover in multi-PFP environments, if an organization fails to create a link between raises and performance, even if they call it a merit plan, we would not expect merit pay to be an effective tool.

Our study is also one of the few studies to examine the effect of LTI on individual employees. When considered independently, PFP for LTI was related to increased performance; however, in this context, the link between pay and performance after partialling out the links with the other pay plans was not significant. This limited the potential incentive effect of LTI when considered in conjunction with the other PFP plans, although it still had a sorting effect. Further research on LTI would be useful, as our results show that, in general, the effectiveness of a compensation plan is a function of its characteristics. We only examined a single LTI plan in this paper; other plans may vary in terms of their vesting requirements and the specific reward granted, and thus can be more complex (Moynihan, 2013).

Motivational theories have strongly supported the underlying mechanisms of PFP plans regarding the extent to which financial rewards can motivate employees to higher performance and the desirable behaviors that organizations expect. Situations have become, for both organizations and employees, more multifaceted due to organizations providing more complex compensation system environments and employees being covered by multiple PFP plans. Future compensation research needs to consider more carefully the effectiveness of PFPs. Indeed, each PFP has a different form and set of characteristics, and all of the different combinations of multiple PFPs that organizations provide will have relative effects on various important outcomes. This creates more complex decision-making and motivational processes that need 
greater research attention.

Overall, a key theoretical contribution from this paper is our demonstration of the potential and utility associated with developing greater theoretical precision (Edwards and Berry, 2010). Simply calling a plan PFP is insufficient, and that while general directional effects are valid, theory can be extended to predict the relative effectiveness of PFP plans. Future theoretical development relevant to PFP plans requires attention to both content (i.e., the characteristics of the plan) and context (i.e., examining a plan in light of other PFP plans that may be in place).

\section{Limitations}

This paper has a number of advantages over previous PFP studies. We used longitudinal data controlling for prior performance to examine both the incentive and sorting effects of PFP plans. The study also considered the different effects of the characteristics of multiple PFP plans simultaneously. Like all research, though, this study is not without limitations, and it is important to point out the key issues which threaten the potential generalizability of our findings.

From a theoretical perspective, this study did not directly assess individual perceptions of motivation; rather, the predictions were based on approximations of the relationships between pay and performance and from the characteristics of the plans and supervisory decisions. While this is not the first study to estimate PFP relationships mathematically (e.g., Kahn \& Sherer, 1990; Salamin \& Hom, 2005; Trevor et al., 1997), it is not a direct test of the internal validity of the related theories. It would certainly be valuable to see how individuals perceive the sort of PFP linkages in which they are operating. While our use of theory and supported hypotheses provide evidence of the external validity of relevant theory, and particularly expectancy theory, our papers does not contribute to testing of the theories' internal validity.

Our single context also limits the generalizability of our findings. Other forms of PFP and 
other simultaneous combinations of PFP plans should be examined to provide greater precision in our understanding of the effectiveness of compensation plans. There are many other types of PFP plans, and even more potential PFP portfolios. Because organizations are more likely to use "hybrid plans" than independent pay plans (Gerhart, 2000; Gerhart \& Fang, 2014; Gomez-Mejia \& Balkin, 1992; Gomez-Mejia, Berrone, \& Franco-Santos, 2010; Milkovich et al., 2013), understanding how the characteristics of multiple PFP plans simultaneously affect performance and voluntary turnover is crucial for organizations to design effective compensation systems.

There are also limitations to the nature of our data. Unaddressed in this paper, there may exist interactions between PFP relationships. It is also possible that pay systems have effects beyond one year. In our analyses, we examine the effect of pay outcomes on performance or turnover in the subsequent year. It is possible, for example, that long-term incentives, may have effects that occur in subsequent years, or the strength of effects may change over time. It is beyond the scope of our study, in addition to the capabilities of our data, to consider the potential multi-year effects of hybrid pay systems, and thus our results may not be fully capturing the set of effects associated with these plans.

In short, our paper represents a single case of a multi-PFP environment, and more research on more and different plans is needed. While performing such research will obviously require significant industry-academic cooperation to provide the sort of data needed to conduct such tests, there is great practical and theoretical value that could be provided by such work.

\section{Implications for Practice}

Given the prevalence of multiple PFP plan environments, our research into the effects of multiple PFP plans operating simultaneously has important implications for practice. First, we show that employees do, on average, respond rationally to incentives. Companies may want to 
avoid raises because of the increase to fixed labor costs, but our findings show that minimizing merit pay means giving up a powerful PFP tool. Raises had larger effects than bonuses and LTI, and only raises had both incentive and sorting effects. Our findings do show that companies can use other pay forms to get the same effects as raises, but it would require stronger PFP links and larger rewards. The trade-off between higher one-time costs versus greater fixed labor costs thus becomes a cost-benefit decision (cf., Sturman, Trevor, Boudreau, \& Gerhart, 2003).

Second, our study shows that companies can apply PFP-related theory to the design of PFP plans, and thus take advantage of evidence-based management (e.g., Rousseau, 2006; Rousseau \& McCarthy, 2007). Companies can specifically look at the degree to which managers link pay and rewards, and adjust policy as necessary to ensure stronger links. Most companies using PFP have individual performance data (WorldatWork, 2012). A related contribution of our study is our demonstration on how companies can use HR data to see how strongly their plans link pay and performance, and thus change policy based on using their HR data.

Third, our results raise interesting questions about the use of bonuses. While bonuses considered independently did have positive incentive and sorting effects, after controlling for the effects of other PFP plans, there was actually a positive effect on turnover. This is consistent with the finding by Sturman and Short (2000), who found a positive effect of bonus satisfaction on turnover intentions after controlling for satisfaction with other pay dimensions. Organizations may benefit by using their available data to make similar tests in their own organizations to see if their pay plans, and bonuses in particular, are having unintended consequences (Pfeffer, 1998).

Fourth and finally, this study emphasizes the importance of the relative effectiveness of different types of PFP plans in multi-PFP plan environment. It is very common today for organizations to provide their employees with more than one type of PFP. As many 
organizations are focusing more on PFP plans, implementing a single or multiple PFP plan(s) is not a differentiator among organizations. With the results of our study, organizations must identify the complexity of pay environments and distinguish between forms and characteristics of different PFP plans and across PFP plan types in order to better understand how these factors influence employees' motivation and decision-making processes. 


\section{REFERENCES}

Aiken, L.S., \& West, S.G. (1991). Multiple regression: Testing and interpreting interactions. Newbury Park: Sage.

Allen, D.G., \& Griffeth, R.W. (2001). Test of a mediated performance-turnover relationship highlighting the moderating roles of visibility and reward contingency. Journal of Applied Psychology, 86, 1014-1021.

Bandiera, O., Barankay, I., \& Rasul, I. (2007). Incentives for managers and inequality among workers: evidence from a firm-level experiment. The Quarterly Journal of Economics, $122,729-773$.

Banker, R.D., Lee, S.Y., Potter, G., \& Srinivasan, D. (1996). Contextual analysis of performance impacts of outcome-based incentive compensation. Academy of Management Journal, 39, 920-948.

Banker, R.D., Lee, S.Y., Potter, G., \& Srinivasan, D. (2001). An empirical analysis of continuing improvements following the implementation of a performance-based compensation plan. Journal of Accounting and Economics, 30, 315-350.

Bartol, K.M., \& Durham, C.C. (2000). Incentives: theory and practice, In Cary L. Cooper, Edwin A, Locke, (Eds.), Industrial and Organizational Psychology (pp.1-33). Blackwell, Oxford.

Bartol, K.M., \& Locke, E.A. (2000). Incentives and motivation, In Sara L. Rynes, and Barry A. Gerhart, (Eds.), Compensation in organizations: current research and practice (pp. 273310). San Francisco: Jossey-Bass.

Batt, R., \& Colvin, A.J.S. (2011). An employment systems approach to turnover: Human resources practices, quits, dismissals and performance. Academy of Management Journal, $54,695-717$. 
Becker, B.E., \& Huselid, M.A. (1992). The incentive effects of tournament compensation systems. Administrative Science Quarterly, 37, 336-350.

Beer M., \& Cannon M.D. (2004). Promise and peril in implementing pay-for-performance. Human Resource Management, 43, 3-20.

Bhattacharya, M., Gibson, D.E., \& Doty, D.H. (2005). The effects of flexibility in employee skills, employee behaviors, and human resource practices on firm performance. Journal of Management, 31, 622-640.

Bloom, M, \& Michel, J. (2002). The relationship among organizational context, pay dispersion, and managerial turnover. Academy of Management Journal, 45, 33-42.

Bonner, S.E., \& Sprinkle, G.B. (2002). The effects of monetary incentives on effort and task performance: theories, evidence, and a framework for research. Accounting, Organizations and Society, 27, 303-345.

Brown, M., Sturman, M.C., \& Simmering, M. (2003). Compensation policy and organizational performance: The efficiency, operational, and financial implications of pay levels and pay structure. Academy of Management Journal, 46, 752-762.

Cadsby, B., Song, F., \& Tapon, F. (2007). Sorting and incentive effects of pay for performance: An experimental investigation. Academy of Management Journal, 50, 387-405.

Cappelli, P., \& Conyon, M.J. (2011). Stock option exercise and gift exchange relationships: Evidence for a large US company. NBER working paper series http://www.nber.org/papers/w16814

Carter, ME, \& Lynch, LJ. (2004). The effect of stock option repricing on employee turnover. Journal of Accounting and Economics, 37, 91-112.

Cascio, W.F., \& Aguinis, H. (2008). Research in industrial and organizational psychology from 
1963 to 2007: changes, choices, and trends. Journal of Applied Psychology, 93, 10621081.

Cohen, K. (2011). Salary budget increases going for a slow ride: WorldatWork 2011-2012 budget survey results. Workspan, September, 30-37.

Core, J.E., \& Guay, W.R. (2001). Stock option plans for nonexecutive employees. Journal of Financial Economics, 61, 253-287.

Daily C.M., Certo S.T., \& Dalton D.R. (2002). Executive stock option repricing: Retention and performance reconsidered. California Management Review, 44: 8-22.

Deadrick, D.L., \& Gibson, P.A. (2007). An examination of the research-practice gap in HR: Comparing topics of interest to HR academics and HR professionals. Human Resource Management Review, 17, 131-139.

Delery, J.E., \& Doty, D.H. (1996). Modes of theorizing in strategic human resource management: Tests of universalistic, contingency, and configurational performance predictions. Academy of Management Journal, 39, 802-835.

Dunford, B.B., Boudreau, J.W., \& Boswell, W.R. (2005). Out-of-the-money: The impact of underwater stock options on executive job search. Personnel Psychology, 58, 67-101.

Dunford, B.B., Oler, D.K., \& Boudreau, J.W. (2008). Underwater stock options and voluntary executive turnover: a multidisciplinary perspective integrating behavioral and economic theories. Personnel Psychology, 61, 687-726.

Edwards, J.R., \& Berry, J.W. (2010). The presence of something or the absence of nothing: Increasing theoretical precision in management research. Organizational Research Methods, 13, 668-689.

Eisenhardt, K.M. (1989). Agency theory: an assessment and review. The Academy of 
Management Review, 14, 57-74.

Eisenberger, R., Rhoades, L., \& Cameron, J. (1999). Does pay for performance increase or decrease perceived self-determination and intrinsic motivation? Journal of Personality and Social Psychology, 77, 1026-1040.

Fusilier, M.R., Ganster, D.C., \& Middlemist, R.D. (1984). A within-person test of the form of the expectancy theory model in a choice context. Organizational Behavior and Human Performance, 34, 323-342.

Gardner, T.M., Wright, P.M., \& Moynihan, L.M. (2011). The impact of motivation, empowerment, and skill-enhancing practices on aggregate voluntary turnover: the mediating effect of collective affective commitment. Personnel Psychology, 64, 315-350.

Gerhart, B. (1990). Voluntary turnover and alternative job opportunities. Journal of Applied Psychology, 75, 467-476.

Gerhart, B. (2000). Compensation strategy and organizational performance. In S. L. Rynes, \& B. Gerhart (Eds.), Compensation in organizations. San Francisco, CA: Jossey-Bass.

Gerhart, B., \& Fang, M. (2014). Pay for (individual) performance: issues, claims, evidence and the role of sorting effects. Human Resource Management Review, 24, 41-52.

Gerhart, B., \& Milkovich, G.T. (1992). Employee compensation: research and practice. In M.D. Dunnette and L.M. Hough (eds.), Handbook of industrial and organizational psychology: $2^{\text {nd }}$ ed., 481-569. Palo Alto, CA: Consulting Psychologists Press, Inc.

Gerhart, B., Minkoff, H.B., \& Olsen, R.N. (1995). Employee compensation: Theory, practice, and evidence. In Ferris, G. R., Rosen, S. D., and Barnum, D. T. (Eds.), Handbook of Human Resource Management. Cambridge, MA: Blackwell.

Gerhart, B., \& Rynes, S.L. (2003). Compensation: theory, evidence, and strategic implications. 
Thousand oaks, CA: Sage.

Gerhart, B., Rynes, S.L., \& Fulmer, I.S. (2009). Pay and performance: individuals, groups, and executives. Academy of Management Annals, 3, 251-315.

Gomez-Mejia, L.R., \& Balkin, D.B. (1989). Effectiveness of individual and aggregate compensation strategies. Industrial Relations, 28, 431-445.

Gomez-Mejia, L. R., \& Balkin, D. B. (1992). Compensation, organizational strategy, and firm performance. Cincinnati, OH: Southwestern Publishing.

Gomez-Mejia, L. R., Berrone, P., \& Franco-Santos, M. (2010). Compensation and organizational performance. Armonk, N.Y.: M.E. Sharpe.

Green, L., \& Myerson, J. (2004). A discounting framework for choice with delayed and probabilistic rewards. Psychological Bulletin, 130, 769-792.

Guthrie, J.P. (2007). Remuneration: Pay effects at work. In Boxall, P., Purcell, J., and Wright, P. (eds.), Oxford Handbook of Human Resource Management, New York: Oxford University Press.

Hall, B.J., \& Knox, T.A. (2004). Underwater options and the dynamics of executive pay-toperformance sensitivities. Journal of Accounting Research, 42, 365- 412.

Harris, M.M., Gilbreath, B., \& Sunday, J.A. (1998). A longitudinal examination of a merit pay system: Relationships among performance ratings, merit increases, and total pay increase. Journal of Applied Psychology, 83, 825-831.

Hayes, R.M. (2004). Discussion of underwater options and the dynamics of executive pay-toperformance sensitivities. Journal of Accounting Research, 42, 413- 421.

Heneman, R.L., \& Werner, J.M. (2005). Merit pay - linking pay to performance in a changing world (2nd ed.). Greenwich, CT: IAP. 
Hull, J.C. (2012). Options, futures and other derivatives (8th ed.). Upper Saddle River, NJ: Prentice Hall.

Jackofsky, E.F., Ferris, K.R., \& Breckenridge, B.G. (1986). Evidence for a curvilinear relationship between job performance and turnover. Journal of Management, 12, 105111.

Jenkins, G.D., Mitra A., Gupta N., \& Shaw J.D. (1998). Are financial incentives related to performance? A meta-analytic review of empirical research. Journal of Applied Psychology, 83, 777-787.

Jones, D.C., \& Kato, T. (1995). The productivity effects of employee stock-ownership plans and bonuses: Evidence from Japanese panel data. American Economic Review, 85, 391-414.

Kahn, L.M., \& Sherer, P.D. (1990). Contingent pay and managerial performance. Industrial and Labor Relations Review, 43, 107S-120S.

Kepes, S., Delery, J., \& Gupta, N. (2009). Contingencies in the effects of pay range on organizational effectiveness. Personnel Psychology, 62, 497-531.

Kwong, J.Y.Y., \& Wong, K.F.E. (2014). Fair or not fair? The effects of numerical framing on the perceived justice of outcomes. Journal of Management, 40, 1558-1582.

Lambert, R.A., Larcker, D.F., \& Weigelt, K. (1993). The structure of organizational incentives. Administrative Science Quarterly, 38, 438-461.

Lance, C.E. (1988). Residual centering, exploratory and confirmatory moderator analysis, and decomposition of effects in path models containing interactions. Applied Psychological Measurement, 12, 163-175.

Lawler, E.E. (1971). Pay and Organizational Effectiveness: A Psychological View. New York: McGraw-Hill. 
Lawler, E.E. (2000). Rewarding Excellence: Pay Strategies for the New Economy. San Francisco, CA: Jossey-Bass, Inc.

Lazear, E.P. (1986). Salaries and piece rates. Journal of Business, 59: 405-431.

Lazear, E. P. (2000). Performance pay and productivity. The American Economic Review, 90, 1346- 1361.

Markham, S. (1988). Pay-for-performance dilemma revisited: Empirical example of the importance of group effects. Journal of Applied Psychology, 73, 172-180.

Mehran, H., \& Yermack, D. (1996). Stock-Based Compensation and Top Management Turnover (May 1996). NYU Working Paper, No. FIN-96-035. Available at SSRN: http://ssrn.com/abstract $=1298300$

Milkovich, G.T., Newman, J.M., \& Gerhart, B. (2013). Compensation (11 ${ }^{\text {th }}$ ed.). New York: McGraw-Hill Companies, Irwin.

Mitchell, T.R., \& Mickel, A.E. (1999). The meaning of money: An individual difference perspective. Academy of Management Review, 24, 568-578.

Mizruchi, M.S., Stearns, L.B., \& Fleischer, A. (2011). Getting a bonus: Social networks, performance, and reward among commercial bankers. Organization Science, 22, 42-59.

Moynihan, D.P. (2013). Long-term incentives: Best practice vs. best fit. Workspan, 58(5), 58-62.

National Center for Employee Ownership. (2012). A statistical profile of employee ownership, Oakland, CA: National Center for Employee Ownership.

Nyberg, A.J., Pieper, J.R., \& Trevor, C.O. (In press). Pay-for-performance's effect on future employee performance: integrating psychological and economic principles toward a contingency perspective. Journal of Management.

Oyer, P., \& Schaefer, S. (2005). Why do some firms give stock options to all employees?: an 
empirical examination of alternative theories. Journal of Financial Economics, 76, 99133.

Pearce, J.L., Stevenson, W.B., \& Perry, J.L. (1985). Managerial compensation based on organizational performance: A time series analysis of the effects of merit pay. Academy of Management Journal, 28, 261-278.

Pfeffer, J. (1998). Six dangerous myths about pay. Harvard Business Review, May-June, 109119.

Raudenbush, S.W., \& Bryk, A.S. (2002). Hierarchical Linear Models: Applications and Data Analysis Methods ( $2^{\text {nd }}$ ed.). Thousand Oaks, CA: Sage.

Raudenbush, S. W., Bryk, A. S., Cheong, Y. F., Congdon, R. T., \& du Toit, M. (2011). HLM 7. Lincolnwood, IL: Scientific Software International Inc.

Rousseau, D.M. (2006). Is there such a thing as “evidence-based management? Academy of Management Review, 31, 256-269.

Rousseau, D.M., \& Ho, V.T. (2000). Psychological contract issues in compensation. In Sara L. Rynes, and Barry A. Gerhart, (eds.), Compensation in organizations: Current research and practice: 273-310. San Francisco: Jossey-Bass.

Rousseau, D.M., \& McCarthy, S. (2007). Educating managers from an evidence-based perspective. Academy of Management Learning and Education, 6, 94-101.

Rynes, S.L., Gerhart, B., \& Parks, L. (2005). Personnel psychology: Performance evaluation and pay for performance. Annual Review of Psychology, 56, 571-600.

Rynes, S.L., Giluk, T.L., \& Brown, K.G. (2007). The very separate worlds of academic and practitioner periodicals in human resource management: Implications for evidence-based management. Academy of Management Journal, 50, 987-1008. 
Salamin, A., \& Hom, P.W. (2005). In search of the elusive U-shaped performance-turnover relationship: are high performing Swiss bankers more liable to quit? Journal of Applied Psychology, 90, 1204-1216.

Schaubroeck, J., Shaw, J.D., Duffy, M.K., \& Mitra, A. (2008). An under-met and over-met expectations model of employee reactions to merit raises. Journal of Applied Psychology, 93, 424-434.

Schmidt, A.M., \& DeShon, R.P. (2007). What to do? The effects of discrepancies, incentives, and time on dynamic goal prioritization. Journal of Applied Psychology, 92, 928-941.

Schwab, D.P. (1991). Contextual variables in employee performance-turnover relationships. Academy of Management Journal, 34, 966-975.

Schwab, D.P., \& Olson, C.A. (1990). Merit pay practices: implications for pay-performance relationships. Industrial and Labor Relations Review, 43, 237S - 255S.

Shaw, J.D., Duffy, M.K., Mitra, A., Lockhart, D.E., \& Bowler, M. (2003). Reactions to merit pay increases: A longitudinal test of a signal sensitivity perspective. Journal of Applied Psychology, 88, 538-544.

Shaw, J.D., \& Gupta, N. (2007). Pay system characteristics and quit patterns of good, average, and poor performers. Personnel Psychology, 60, 903-928.

Steel, P., \& König, C.J. (2006). Integrating theories of motivation. Academy of Management Review, 31, 889-913.

Sturman, M.C. (2003). Searching for the inverted U-shaped relationship between time and performance: meta-analyses of the experience/performance, tenure/performance, and age/performance relationships. Journal of Management, 29, 609-640.

Sturman, M.C. (2007). The past, present, and future of dynamic performance research. Research 
in Personnel and Human Resource Management, 26, 49-110.

Sturman, M.C., Cheramie, R.A., \& Cashen, L.H. (2005). The Impact of Job Complexity and Performance Measurement on the temporal Consistency, Stability, and Test-Retest Reliability of Employee Job Performance Ratings. Journal of Applied Psychology, 90, 269-283.

Sturman, M.C., Shao, L., \& Katz, J. (2012). The effect of culture on the curvilinear relationship between performance and turnover. Journal of Applied Psychology, 97, 46-62.

Sturman, M.C., \& Short, J.C. (2000). Lump-sum bonus satisfaction: testing the construct validity of a new pay satisfaction dimension. Personnel Psychology, 53, 673-700.

Sturman, M.C., Trevor, C.O., Boudreau, J.W., \& Gerhart, B. (2003). Is it worth it to win the talent war? Evaluating the utility of performance-based pay. Personnel Psychology, 56, 997-1035.

Toh, S.M., Morgeson, F.P., \& Campion, M.A. (2008). Human resource configurations: Investigating fit with the organizational context. Journal of Applied Psychology, 93, 864-882.

Trevor, C.O., Gerhart, B., \& Boudreau, J.W. (1997). Voluntary turnover and job performance. Curvilinearity and the moderating influences of salary growth and promotions. Journal of Applied Psychology, 82, 44-61.

Trevor, C.O., Reilly, G., \& Gerhart, B. (2012). Reconsidering pay dispersion's effect on the performance of interdependent work: Reconciling sorting and pay inequality. Academy of Management Journal, 55, 585-610.

Vancouver, J.B., Weinhardt, J.M., \& Schmidt, A.M. (2010). A formal, computational theory of multiple-goal pursuit: Integrating goal-choice and goal-striving processes. Journal of Applied 
Psychology, 95, 985-1008.

Van Eerde, W., \& Thierry, H. (1996). Vroom's expectancy models and work-related criteria: A meta-analysis. Journal of Applied Psychology, 81, 575-586.

Viswesvaran, C., Ones, D.S., \& Schmidt, F.L. (1996). Comparative analysis of the reliability of job performance ratings. Journal of Applied Psychology, 81, 557-574.

Vroom, V.H. (1964). Work and motivation. New York: Wiley.

Williams, C.R. (1999). Reward contingency, unemployment and functional turnover. Human

Resource Management Review, 9, 549-576.

WorldatWork (2010). Compensation Programs and Practices 2010. WorkatWork: Washington, DC.

WorldatWork (2012). Compensation Programs and Practices 2012. WorkatWork: Washington, DC.

Wright, T.A,. \& Cropanzano, R.R. (1998). Emotional exhaustion as a predictor of job performance and voluntary turnover. Journal of Applied Psychology, 83, 486-493.

Wright, P.M., Gardner, T.M., Moynihan, L.M., \& Allen, M.R. (2005). The relationship between HR practices and firm performance: Examining causal order. Personnel Psychology, 58, 409-446.

Zenger, T.R. (1992). Why do employers only reward extreme performance? Examining the relationships among performance, pay, and turnover. Administrative Science Quarterly, 37, 198-219. 


\section{TABLE 1}

Summary Statistics for Analyses of Job Performance

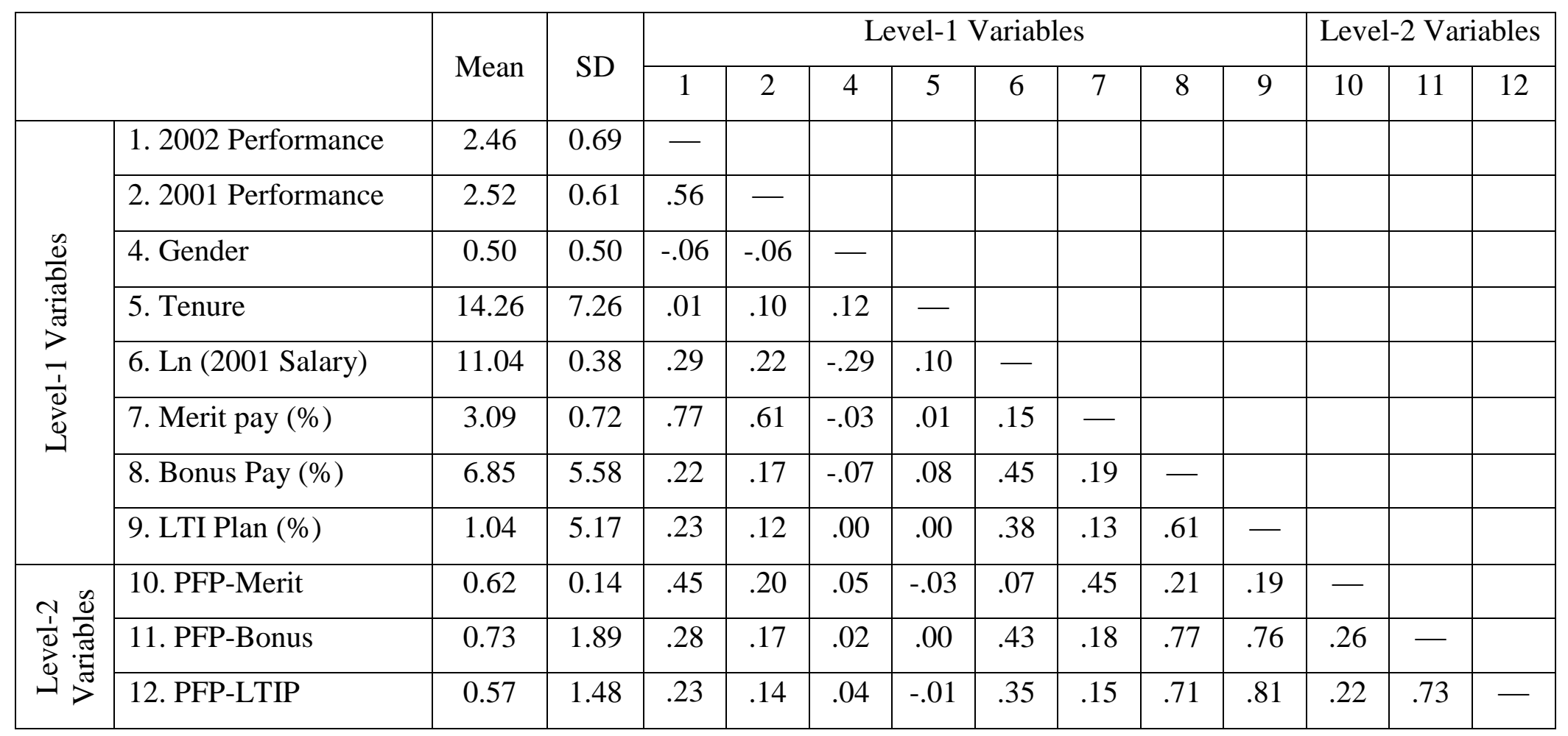

Notes: $\mathrm{N}=635$. Correlations greater than .08 are $\mathrm{p}<.05$. 
TABLE 2

Summary Statistics for Analyses of Turnover

\begin{tabular}{|c|c|c|c|c|c|c|c|c|c|c|c|c|c|c|}
\hline & & Mean & $\mathrm{SD}$ & \multicolumn{8}{|c|}{ Level-1 Variables } & \multicolumn{3}{|c|}{ Level-2 Variables } \\
\hline & & & & 1 & 2 & 3 & 4 & 5 & 6 & 7 & 8 & 9 & 10 & 11 \\
\hline \multirow{8}{*}{ 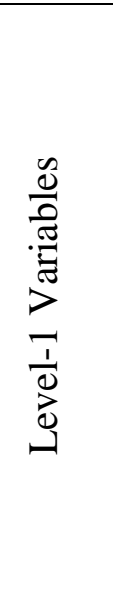 } & 1. 2001 Performance & 2.49 & 0.63 & - & & & & & & & & & & \\
\hline & 2. Turnover & 0.12 & 0.33 & -.14 & - & & & & & & & & & \\
\hline & 3. Gender & 0.50 & 0.50 & -.06 & .01 & - & & & & & & & & \\
\hline & 4. Tenure & 13.80 & 11.04 & .12 & -.17 & .09 & - & & & & & & & \\
\hline & 5. Ln (2001 Salary) & 11.04 & 0.39 & .21 & -.02 & -.32 & .12 & - & & & & & & \\
\hline & 6. Merit pay (\%) & 3.08 & 0.74 & .59 & -.04 & -.02 & .00 & .12 & - & & & & & \\
\hline & 7. Bonus Pay (\%) & 7.02 & 6.46 & .13 & -.07 & -.10 & .06 & .47 & .14 & - & & & & \\
\hline & 8. LTI Plan (\%) & 1.19 & 6.41 & .08 & -.06 & -.04 & -.01 & .40 & .10 & .64 & - & & & \\
\hline \multirow{3}{*}{ 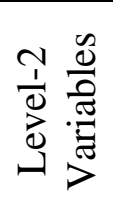 } & 9. PFP-Merit & 0.62 & 0.14 & .13 & -.03 & -.07 & -.03 & .04 & .43 & .18 & .17 & - & & \\
\hline & 10. PFP-Bonus & 0.73 & 1.89 & .15 & .01 & .01 & .00 & .41 & .17 & .75 & .73 & .24 & - & \\
\hline & 11. PFP-LTIP & 0.57 & 1.48 & .12 & -.02 & .03 & -.01 & .13 & .14 & .68 & .78 & .21 & .72 & - \\
\hline
\end{tabular}

Notes: $\mathrm{N}=720$. Correlations greater than .08 are $\mathrm{p}<.05$. 
TABLE 3

Separate and Partialled Effects of PFP Plans

\begin{tabular}{|c|c|c|c|c|c|}
\hline Variable & Model 1 & Model 2a & Model 2b & Model 2c & Model 3 \\
\hline \multicolumn{6}{|c|}{ For Intercept (Random Effect) } \\
\hline Intercept & $\begin{array}{l}-3.06 \\
(0.68) * * *\end{array}$ & $\begin{array}{l}-2.38 \\
(0.62) * * *\end{array}$ & $\begin{array}{l}-2.48 \\
(0.71)^{* * *}\end{array}$ & $\begin{array}{l}-2.84 \\
(0.65) * * *\end{array}$ & $\begin{array}{l}-2.93 \\
(0.62) * * *\end{array}$ \\
\hline PFP-Merit & & $\begin{array}{l}100.98 \\
(28.16)^{* * *}\end{array}$ & & & $\begin{array}{l}88.22 \\
(28.94) * *\end{array}$ \\
\hline PFP-Bonus & & & $\begin{array}{l}8.09 \\
(1.86)^{* * *}\end{array}$ & & $\begin{array}{l}8.09 \\
(4.81)^{*}\end{array}$ \\
\hline PFP-LTI & & & & $\begin{array}{l}8.63 \\
(2.31)^{* * * *}\end{array}$ & $\begin{array}{l}-2.06 \\
(5.84)\end{array}$ \\
\hline 2001 Performance & $\begin{array}{l}0.14 \\
(0.048) * *\end{array}$ & $\begin{array}{l}0.15 \\
(0.048) * *\end{array}$ & $\begin{array}{l}0.14 \\
(0.047)^{* *}\end{array}$ & $\begin{array}{l}0.14 \\
(0.048)^{* * *}\end{array}$ & $\begin{array}{l}0.15 \\
(0.048)^{* *}\end{array}$ \\
\hline Gender & $\begin{array}{l}0.0087 \\
(0.034)\end{array}$ & $\begin{array}{l}0.0034 \\
(0.031)\end{array}$ & $\begin{array}{l}-0.0093 \\
(0.034)\end{array}$ & $\begin{array}{l}-0.0051 \\
(0.034)\end{array}$ & $\begin{array}{l}-0.012 \\
(0.032)\end{array}$ \\
\hline Tenure & $\begin{array}{l}-0.0034 \\
(0.0027)\end{array}$ & $\begin{array}{l}-0.0027 \\
(0.0026)\end{array}$ & $\begin{array}{l}-0.0021 \\
(0.0026)\end{array}$ & $\begin{array}{l}-0.0026 \\
(0.0027)\end{array}$ & $\begin{array}{l}-0.0017 \\
(0.0025)\end{array}$ \\
\hline Ln (2001 Salary) & $\begin{array}{l}0.34 \\
(0.067) * * *\end{array}$ & $\begin{array}{l}0.33 \\
(0.064) * * *\end{array}$ & $\begin{array}{l}0.29 \\
(0.060) * * *\end{array}$ & $\begin{array}{l}0.32 \\
(0.064) * * *\end{array}$ & $\begin{array}{l}0.28 \\
(0.057)^{* * * *}\end{array}$ \\
\hline Merit pay\% & $\begin{array}{l}61.61 \\
(5.71)^{* * *}\end{array}$ & $\begin{array}{l}57.35 \\
(6.62) * * *\end{array}$ & & & $\begin{array}{l}57.98 \\
(6.60)^{* * *}\end{array}$ \\
\hline Bonus Pay\% & $\begin{array}{l}-0.54 \\
(0.95)\end{array}$ & & $\begin{array}{l}-1.07 \\
(0.65)\end{array}$ & & $\begin{array}{l}-1.27 \\
(0.94)\end{array}$ \\
\hline LTI\% & $\begin{array}{l}0.082 \\
(1.01) \\
\end{array}$ & & & $\begin{array}{l}-1.22 \\
(0.96) \\
\end{array}$ & $\begin{array}{l}-0.47 \\
(0.93) \\
\end{array}$ \\
\hline \multicolumn{6}{|l|}{ Fit Statistics } \\
\hline Model Likelihood & -341.50 & -325.60 & -331.17 & -333.53 & -315.73 \\
\hline Sigma $^{2}$ & 0.1490 & 0.1473 & 0.1478 & 0.1477 & 0.1464 \\
\hline $\begin{array}{l}\% \text { LV-1 Var } \\
\text { Explained }\end{array}$ & $68 \%$ & $69 \%$ & $69 \%$ & $69 \%$ & $69 \%$ \\
\hline $\begin{array}{l}\text { Random Effects } \\
\text { Variance Comp }\end{array}$ & $\begin{array}{l}0.0319 * * * \\
\text { onent }\end{array}$ & $0.0229 * * *$ & $0.0255 * * *$ & $0.0291 * * *$ & $0.0196 * * *$ \\
\hline $\begin{array}{l}\text { Percent Variance } \\
\text { Component Exp }\end{array}$ & $\begin{array}{c}79 \% \\
\text { plained }\end{array}$ & $95 \%$ & $95 \%$ & $94 \%$ & $96 \%$ \\
\hline
\end{tabular}

Notes: $\mathrm{N}($ level-1) $=635 ; \mathrm{N}($ level-2) $=88 . * \mathrm{p}<.05 ; * * \mathrm{p}<.01 ; * * * \mathrm{p}<.001$. For the null model, Sigma2 $=0.4693$. For the random intercepts model, likelihood $=-624.98$, Sigma $^{2}=0.3510(25 \%$ explained), the random effects variance component $=0.1458$ (significant at $\mathrm{p}<.001$ ), and ICC(1) $=0.31$. 
TABLE 4

Prediction of Turnover

\begin{tabular}{|c|c|c|c|c|c|}
\hline Variable & Model 1 & Model 2a & Model 2b & Model 2c & Model 3 \\
\hline \multicolumn{6}{|c|}{ For Intercept (Random Effect) } \\
\hline Intercept & $\begin{array}{l}-1.45 \\
(4.82)\end{array}$ & $\begin{array}{l}-3.42 \\
(4.31)\end{array}$ & $\begin{array}{l}-1.90 \\
(4.70)\end{array}$ & $\begin{array}{l}-5.70 \\
(4.63)\end{array}$ & $\begin{array}{l}-2.00 \\
(5.51)\end{array}$ \\
\hline \multicolumn{2}{|l|}{ PFP-Merit } & $\begin{array}{l}-262.34 \\
(143.36)^{*}\end{array}$ & & & $\begin{array}{l}-227.10 \\
(115.77)^{*}\end{array}$ \\
\hline \multicolumn{2}{|l|}{ PFP-Bonus } & & $\begin{array}{l}-2.77 \\
(13.92)\end{array}$ & & $\begin{array}{l}92.21 \\
(26.40) * * *\end{array}$ \\
\hline \multicolumn{2}{|l|}{ PFP-LTI } & & & $\begin{array}{l}-76.05 \\
(50.27)^{\dagger}\end{array}$ & $\begin{array}{l}-242.17 \\
(78.77)^{* *}\end{array}$ \\
\hline \multicolumn{6}{|c|}{2001 Performance (linear) } \\
\hline Intercept & $\begin{array}{l}-0.54 \\
(0.27)^{*}\end{array}$ & $\begin{array}{l}-0.73 \\
(0.27)^{* *}\end{array}$ & $\begin{array}{l}-0.53 \\
(0.19)^{* *}\end{array}$ & $\begin{array}{l}-1.14 \\
(0.48)^{* *}\end{array}$ & $\begin{array}{l}-2.05 \\
(0.59)^{* * *}\end{array}$ \\
\hline \multicolumn{2}{|l|}{ PFP-Merit } & $\begin{array}{l}-823.81 \\
(223.88) * * *\end{array}$ & & & $\begin{array}{l}-793.07 \\
(185.76) * * *\end{array}$ \\
\hline \multicolumn{2}{|l|}{ PFP-Bonus } & & $\begin{array}{l}-30.33 \\
(16.30)^{*}\end{array}$ & & $\begin{array}{l}21.29 \\
(27.15)\end{array}$ \\
\hline \multicolumn{2}{|l|}{ PFP-LTI } & & & $\begin{array}{l}-162.77 \\
(88.55)^{*}\end{array}$ & $\begin{array}{l}-298.61 \\
(123.49)^{* *}\end{array}$ \\
\hline \multicolumn{6}{|c|}{2001 Performance (Quadratic) } \\
\hline Intercept & $\begin{array}{l}0.71 \\
(0.25)^{* *}\end{array}$ & $\begin{array}{l}0.64 \\
(0.22)^{* *}\end{array}$ & $\begin{array}{l}0.60 \\
(0.21)^{* *}\end{array}$ & $\begin{array}{l}0.20 \\
(0.33)\end{array}$ & $\begin{array}{l}-0.083 \\
(0.41)\end{array}$ \\
\hline PFP-Merit & & $\begin{array}{l}-497.56 \\
(241.34)^{*}\end{array}$ & & & $\begin{array}{l}-332.38 \\
(253.46)^{\dagger}\end{array}$ \\
\hline PFP-Bonus & & & $\begin{array}{l}-31.67 \\
(18.93)^{*}\end{array}$ & & $\begin{array}{l}38.69 \\
(43.14)\end{array}$ \\
\hline PFP-LTI & & & & $\begin{array}{l}-120.65 \\
(53.87)^{*}\end{array}$ & $\begin{array}{l}-222.78 \\
(86.00)^{* *}\end{array}$ \\
\hline Gender & $\begin{array}{l}0.25 \\
(0.25)\end{array}$ & $\begin{array}{l}0.27 \\
(0.27)\end{array}$ & $\begin{array}{l}0.32 \\
(0.27)\end{array}$ & $\begin{array}{l}0.39 \\
(0.27)\end{array}$ & $\begin{array}{l}0.34 \\
(0.31)\end{array}$ \\
\hline Tenure & $\begin{array}{l}-0.088 \\
(0.020)^{* * * *}\end{array}$ & $\begin{array}{l}-0.086 \\
(0.021)^{* * * *}\end{array}$ & $\begin{array}{l}-0.094 \\
(0.022)^{* * * *}\end{array}$ & $\begin{array}{l}-0.098 \\
(0.022)^{* * *}\end{array}$ & $\begin{array}{l}-0.095 \\
(0.023) * * *\end{array}$ \\
\hline
\end{tabular}




\begin{tabular}{|c|c|c|c|c|c|}
\hline Ln (2001 Salary) & $\begin{array}{l}0.023 \\
(0.43)\end{array}$ & $\begin{array}{l}0.20 \\
(0.39)\end{array}$ & $\begin{array}{l}0.070 \\
(0.43)\end{array}$ & $\begin{array}{l}0.39 \\
(0.42)\end{array}$ & $\begin{array}{l}0.020 \\
(0.49)\end{array}$ \\
\hline Merit pay\% & $\begin{array}{l}11.38 \\
(28.49)\end{array}$ & $\begin{array}{l}31.21 \\
(23.10)\end{array}$ & & & $\begin{array}{l}23.55 \\
(23.16)\end{array}$ \\
\hline Bonus Pay\% & $\begin{array}{l}7.51 \\
(5.56)\end{array}$ & & $\begin{array}{l}2.70 \\
(3.69)\end{array}$ & & $\begin{array}{l}-1.50 \\
(6.39)\end{array}$ \\
\hline LTI\% & $\begin{array}{l}-10.23 \\
(8.92) \\
\end{array}$ & & & $\begin{array}{l}4.44 \\
(6.31) \\
\end{array}$ & $\begin{array}{l}8.67 \\
(10.72) \\
\end{array}$ \\
\hline \multicolumn{6}{|l|}{ Fit Statistics } \\
\hline \multicolumn{6}{|c|}{ Model Likelihood } \\
\hline $\begin{array}{l}\text { \% LV-1 Var } \\
\text { Explained }\end{array}$ & $10 \%$ & $13 \%$ & $11 \%$ & $11 \%$ & $13 \%$ \\
\hline $\begin{array}{l}\text { Random Effects } \\
\text { Variance Comp }\end{array}$ & $\begin{array}{l}0.3406 \\
\text { nent }\end{array}$ & 0.3606 & 0.3872 & 0.4063 & 0.1877 \\
\hline $\begin{array}{l}\text { Percent Variance } \\
\text { Component Ex }\end{array}$ & $\begin{array}{l}17 \% \\
\text { lained }\end{array}$ & $12 \%$ & $5 \%$ & $1 \%$ & $54 \%$ \\
\hline
\end{tabular}

Notes: $\mathrm{N}\left(\right.$ level-1) $=720 ; \mathrm{N}\left(\right.$ level-2) $=88 .{ }^{\dagger} \mathrm{p}<.10 ; * \mathrm{p}<.05 ; * * \mathrm{p}<.01 ; * * * \mathrm{p}<.001$. For the purpose of reporting level-1 variance explained in the turnover model, as no level-1 sigma is given for a dichotomous outcome, the table reports the sigma ${ }^{2}$ for a normal (continuous) outcome variable. All other turnover analyses are based on the more appropriate Bernoulli outcome model. 